\title{
JURNAL EMPATI
}

Edukasi Masyarakat, Pengabdian dan Bakti

Vol.3., No.2, Oktober 2021 Hal 119 - 126

ISSN 2774-4442 (print) dan ISSN 2774-2296 (online)

\section{EDUKASI KESEHATAN REPRODUKSI BERBASIS THIBUN NABAWI MENUJU KAMPUNG KB BERKEMANDIRIAN JASMANI DAN ROHANI}

\section{THIBUN NABAWI-BASED EDUCATION OF REPRODUCTIVE HEALTH TOWARDS A KB VILLAGE OF PHYSICAL AND SPIRITUAL INDEPENDENCE}

\author{
Rina Sri Widayati ${ }^{1)}$, Dewi Kartika Sari ${ }^{2)}$, Mutiara Alisyah Putri ${ }^{3)}$,Mila \\ Dwi Jayanti ${ }^{4}$ \\ 1,2 Dosen Fakultas Ilmu Kesehatan Universitas Aisyiyah Surakarta \\ ${ }^{3.4}$ Mahasiswa Sarjana Kebidanan Universitas Aisyiyah Surakarta \\ *Corresponding author: rinasriwidayati@gmail.com
}

Kata Kunci:

edukasi;

remaja;

kesehatan;

reproduksi,

thibun nabawi

Keywords:

education;

teenager; health;

reproduction,

thibun nabawi

\section{ABSTRAK}

Angka prevalensi tahun 2006, 25\% - 50\% candidiasis, 20\%-40\% bacterial vaginosis dan 5\%-15\% trichomoniasis. Penyebab utama keputihan patologis ialah infeksi (jamur, kuman, parasit dan virus). Remaja mengeluh keputihan sehingga meras tidak nyaman, salah satu penyebabnya jarang menganti celana dalam, tidak menganti pembalut saat menstruasi.Salah satu edukasi tentang kesehatan reproduksi berbasis Thibun Nabawi. Metode: Metode yang diterapkan dalam pengabdian masyarakat adalah pendekatan edukatif dan sebelumnya dilakukan kajian mendalam tentang keluhan yang dialami. Diawali pemberian materi mengenai kesehatan reproduksi berbasis thibun nabawi. Kegiatan pengabdian masyarakat yang telah dilakukan di Taman Cerdas Puntadewa Kelurahan Pucangsawit Jebres Surakarta. Kegiatan pengabdian masyarakat diikuti oleh 7 orang. Hasil: Kegiatan pengabdian masyarakat yang dilakukan dengan beberapa tahapan, mulai analisis masalah, kajian dalam, edukasi, pendampingan serta evaluasi sebelum dan sesudah, Terjadi peningkatan presentase sebelum dan sesudah kegiatan. Diantaranya meliputi indikator definisi keputihan, factor pemicu keputihan,kandungan dalam Al Quran, dampak keputihan, cara mencegah dan junub anjuran Rasulullah.

\section{ABSTRACT}

The prevalence rate in 2006, 25\% - 50\% candidiasis, 20\%-40\% bacterial vaginosis and $5 \%-15 \%$ trichomoniasis. The main cause of pathological vaginal discharge is infection (fungi, germs, parasites and viruses). Teenagers complain of vaginal discharge that makes them feel uncomfortable, one of the reasons is that they rarely change their underwear, don't change sanitary napkins during menstruation. One of the educations about reproductive health is based on Thibun Nabawi. Methods: The method applied in community service is an educative approach and previously an in-depth study was conducted on the complaints experienced. It was started by giving material on thibun nabawi-based reproductive health. Community service activities that have been carried out at Smart Park Puntadewa, Pucangsawit Jebres, Surakarta. The community service activity was attended by 7 people. Results: Community service activities carried out in several stages, starting from problem analysis, internal studies, education, mentoring and evaluation before and after, there was an increase in the percentage before and after the activity. Among them include indicators of the definition of vaginal discharge, factors that trigger vaginal discharge, the content in the Koran, the impact of vaginal discharge, how to prevent and follow the recommendations of the Prophet. 


\section{PENDAHULUAN}

Masa remaja merupakan masa transisi antara masa kanak-kanak dengan dewasa. Remaja pada tahap ini belum mencapai kematangan mental dan sosial sehingga remaja harus menghadapi banyak tekanan emosi dan sosial yang saling bertentangan. Remaja akan mengalami perubahan fisik yang cepat ketika remaja memasuki masa puber. Slah satu dari perubahan fisik tersebut adalah kemampuan untuk melakukan proses reproduksi. Tetapi banyak fenomena memperlihatkan sebagian remaja belum mengetahui dan memahami tentang kesehatan reproduksi, misalnya tentang menstruasi, keputihan dan terjadinya kehamilan. (Ernawati, 2018)

Kasus seputar reproduksi remaja sekarang semakin meningkat, disebabkan ketidakpahaman remaja terhadap berbagai aspek reproduksi yang berhubungan dengan dirinya sendiri. Peningkatan kualitas kesehatan reproduksi remaja dapat dilakukan dengan memperhatikan masalah komunikasi kesehatan. Permasalahan remaja mengenai seksualitas dan kesehatan reproduksi kian lama dirasakan kian komplek dan memprihatinkan. Masalah yang terjadi pada kesehatan reproduksi remaja bisa berupa hubungan seks sebelum menikah, putus sekolah karena hamil, pasangan tidak bertanggung jawab, penggunaan alat kontrasepsi, aborsi, terinfeksi HIV/AIDS, penyakit menular seksual dan penggunaan obat-obat terlarang. (Ernawati, 2018)

Remaja perlu untuk diberian informasi tentang kesehatan reproduksi, selain agar remaja mendapatkan kejelasan mengenai alat reproduksinya dengan benar, juga dapat membantu mereka mengenal dirinya sendiri, sehingga remaja bisa lebih bertanggung jawab pada kesehatan reproduksinya.(Ernawati, 2018)

Helmy Ilmiawati, Kuntoro Departemen Biostatistika dan Kependudukan FKM UNAIR menyebutkan Data WHO (2007) menyebutkan, angka prevalensi tahun 2006, 25\% - 50\% candidiasis, $20 \%-40 \%$ bacterial vaginosis dan 5\%$15 \%$ trichomoniasis. Penyebab utama keputihan patologis ialah infeksi (jamur, kuman, parasit dan virus). Keputihan patologis dapat juga disebabkan karena kurangnya perawatan remaja putri terhadap alat genetalia seperti mencuci vagina dengan air yang tergenang di ember, menggunakan pembilas secara berlebihan, memakai celana dengan bahan yang tidak menyerap keringat, jarang mengganti celana dalam, dan tak sering mengganti pembalut saat menstruasi (Aulia, 2012). Kurang lebih $75 \%$ wanita di Indonesia yang tidak tahu tentang keputihan sehingga mereka menganggap keputihan sebagai hal yang sudah biasa dan sepele, di samping itu rasa malu ketika para wanita/remaja mengalami keputihan kerap membuat wanita/remaja tersebut enggan berkonsultasi ke dokter. Padahal keputihan tidak bisa dianggap sepele, karena akibat dari keputihan ini sangat fatal bila lambat ditangani tidak hanya bisa mengakibatkan kemandulan dan hamil di luar kandungan. Keputihan juga bisa merupakan gejala awal dari kanker leher rahim (kanker serviks) yang bisa berujung pada kematian kalau tidak dikonsultasikan pada petugas kesehatan sejak dini (Sutarno, 2003). Setiap tahunnya ada 8000 perempuan di Indonesia meninggal dikarenakan menderita penyakit kanker serviks.

Permasalahan utama pada remaja adalah butuhnya edukasi tentang kesehatan, salah satunya yaitu pengetahuan mengenai Kesehatan Alat Reproduksi 
Remaja. Target luaran yang diharapkan dari penyuluhan kesehatan dengan salah satu media pembelajaran berupa poster .Hasil penyuluhan $100 \%$ materi dapat tersampaikan dengan baik dan masyarakat bisa menerima serta memahaminya. $90 \%$ masyarakat dapat mengaplikasikan materi dalam kehidupan sehari-hari.

\section{METODE}

Kegiatan pengabdian masyarakat dilakukan di Kampung KB Pucangsawit, Surakarta, tepatnya di Taman Cerdas RW 13 Pucangsawit, Surakarta dengan melibatkan kelompok PIK-R Kampung KB Pucangsawit. Metode pelaksanaan kegiatan pengabdian ini dilakukan sebagai berikut: Koordinasi dengan pokja Kampung KB, pengelola Taman Cerdas dan tim PLKB Pucangsawit untuk menjelaskan maksud dan tujuan serta mendisuksikan persoalan yang dihadapi remaja salah satunya tentang kesehatan reproduksi. Ini bertujuan ini untuk menentukan metode atau program penyuluhan yang tepat. Pengumpulan data melalui indept interview kepada remaja yang mengalami kesehatan reproduksi seperti keputihan gatal dan berbau. Metode ini dilakukan agar lebih terarah dan tepat sasaran. Kedua, Edukasi dan pendampingan dilakukan secara interpersonal sehingga ada keterbukaan antara educator dan sasaran Dalam kegiatan ini diberikan beberapa informasi dan isu-isu yang dihadapi terkait kesehatan reproduksi dengan internalisasi muatan thibun Nabawi yang pada dasarnya semua ada aturan yang seperti tertuang dalam Al Quran dan Assunah . Dimulai dengan pemaparan materi tentang kesehatan reproduksi yang berbasis thibun Nabawi untuk meningkatkan pemahaman masyarakat secara ilmiah, selanjutnya dilakukan tanya jawab. Ketiga, simulasi dengan menggunakan phantom genetalia perempuan untuk mempraktekkan secara langsung bagaimana cara menjaga genetalia dengan tepat sesuai Al quran dan Assunah. Penerapan metode simulasi ini diharapkan dapat meningkatkan pengetahuan dan mengatasi permasalahan yang berkaitan dengan informasi kesehatan reproduksi. Setelah menyelesaikan kegiatan pengabdian maka dilakukan monitoring dan evaluasi untuk mengetahui tingkat pengetahuan sasaran PIK-R

\section{HASIL DAN PEMBAHASAN}

Para remaja masih banyak yang belum mengetahui cara menjaga kesehatan alat reproduksi itu apa dan gejala abnormal yang mungkin terjadi, serta cara pencegahannya seperti apa. Kurangnya pengetahuan remaja akan pentingnya menjauhi hal-hal yang dapat mengakibatkan gangguan kesehatan alat reproduksi remaja yang menjadi pendorong dilaksanakannya penyuluhan ini. Prornotif, prefentif, kuratif dan rehabilitatif kita jelaskan supaya remaja di daerah masing-masing mulai paham dan mengerti bahwa pentingnya untuk melakukan cara-cara pencegahan gangguan kesehatan alat reproduksi remaja.

Hasil dari evaluasi yang kami lakukan, para remaja PIK-R yang sebelumnya tidak mengetahui apa itu gangguan kesehatan alat reproduksi remaja dan beberapa faktor resikonya, akhirnya menjadi lebih mengetahui dan paham. Para remaja juga menjadi paham dengan cara pencegahan dan pola hidup sehat agar terhindar dari gangguan kesehatan alat reproduksi remaja. Semua edukasi dari kami pun dapat diterima dengan baik oleh para remaja..Hasil evaluasi kegiatan kami sajikan dalam tabel 1.1 dibawah ini 
Tabel 1.1 Evaluasi sebelum dan sesudah pengabdian masyarakat

\begin{tabular}{lcccc}
\hline \multicolumn{1}{c}{ PERNYATAAN } & \multicolumn{2}{c}{ SEBELUM } & SESUDAH \\
\cline { 2 - 5 } & $\mathbf{B}$ & $\mathbf{S}$ & $\mathbf{B}$ & $\mathbf{S}$ \\
\hline Definisi/pengertian keputihan & $3(42,8)$ & $4(57,2)$ & $5(71,4)$ & $2(28,6)$ \\
& & & & \\
\hline Keputihan normal/fisiologis & $4(57,2)$ & $3(42,8)$ & $4(57,2)$ & $3(42,8)$ \\
\hline Faktor-faktor yang memicu keputihan & $2(28,6)$ & $5(71,4)$ & $4(57,2)$ & $3(42,8)$ \\
\hline Keputihan abnormal. & $3(42,8)$ & $4(57,2)$ & $3(42,8)$ & $4(57,2)$ \\
\hline Kandungan Al Qur'an surat Al Baqarah ayat 223 & $1(14,3)$ & $6(85,7)$ & $4(57,2)$ & $3(42,8)$ \\
\hline Dampak Keputihan patologis/tidak normal & $4(57,2)$ & $3(42,8)$ & $5(71,4)$ & $2(28,6)$ \\
\hline Cara mencegah keputihan & $3(42,8)$ & $4(57,2)$ & $6(85,7)$ & $1(14,3)$ \\
\hline Tata cara mandi junub sesuai hadits Rasulullah, & & & & \\
\hline Ciri-ciri keputihan normal & $2(28,6)$ & $4(57,2)$ & $4(57,2)$ & $2(28,6)$ \\
\hline
\end{tabular}

Berdasarkan table 1.1 diperoleh peningkatan prosentase sebelum dan sesudah kegiatan diantaranya indicator definisi keputihan, factor pemicu keputihan,kandungan dalam Al Quran, dampak keputihan, cara mencegah dan junub anjuran Rasulullah.

Kegiatan pengabdian dilaksanakan pada hari Senin tangal 14 Juni 2021. Jumlah peserta yaitu 7 orang. Karena, kurangnya pemahaman para remaja tentang gangguan kesehatan alat reproduksi remaja, kita sebagai educator berupaya memberikan penyuluhan mengenai "Edukasi Pencegahan gangguan kesehatan alat reproduksi remaja berbasis thibun Nabawi " yang meliputi: Membedakan Keputihan Patologis dan Non Patologis yang sering terjadi pada Remaja., Siklus Menstruasi pada Remaja., Cara Menjaga Kesehatan Daerah genetalia
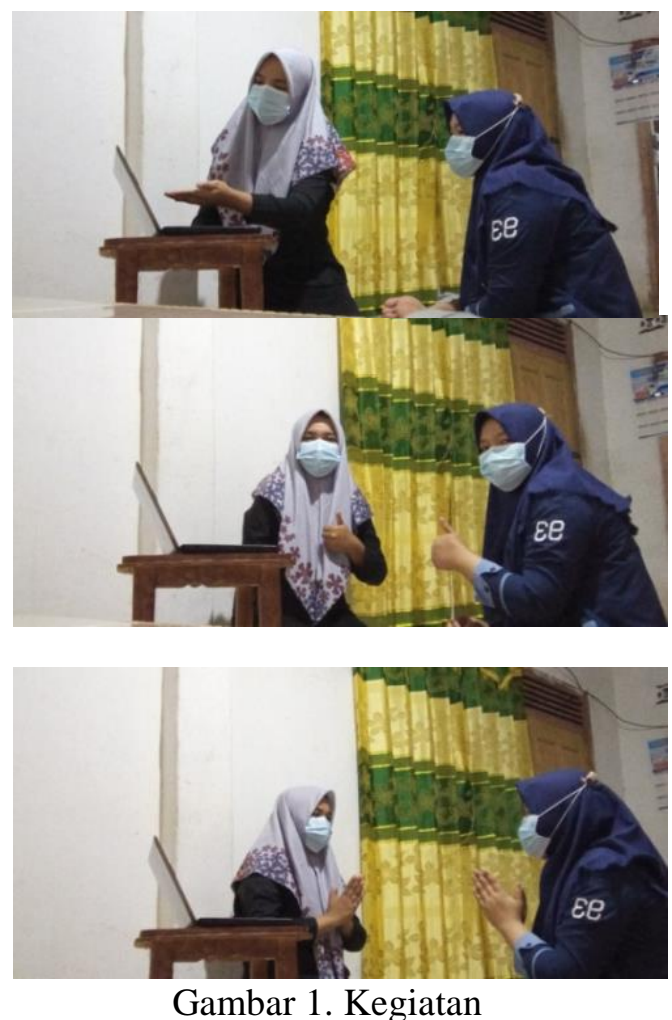
Keputihan merupakan salah satu tanda dari proses ovulasi yang terjadi di dalam tubuh. Selain itu, keputihan juga merupakan salah satu tanda dari suatu penyakit. Keputihan ada yang bersifat fisiologi dan patologis. Keputihan bersifat fisiologis yaitu keputihan yang timbul akibat proses alami dalam tubuh. Keputihan bersifat patologis yaitu keputihan yang timbul karena infeksi dari jamur, bakteri dan virus. Keputihan patologis merupakan tanda dari adanya kelainan alat repoduksi sehingga jumlah, warna, dan baunya perlu diperhatikan.(Qiao, Cui and Cui, 2007). Proses Fisiologis Suci. Proses menstruasi pada wanita terjadi dalam tiga tahapan, yaitu proliferasi, sekresi, dan menstruasi. Pada masing-masing poses mempunyai pengaruh yang berbeda terhadap endometrium. Keputihan secara fisiologis terjadi sebelum menstruasi karena pengaruh dari proses menstruasi yang melibatkan hormon estrogen dan progesteron. Pada proses proliferasi terjadi pembentukan hormon estrogen oleh ovarium yang menyebabkan pengeluaran sekret yang berbentuk seperti benang, tipis dan elastis. Hormon estrogen berperan dalam produksi sekret pada fase sekretorik, merangsang pengeluaran sekret pada saat wanita terangsang serta menentukan kadar zat gula dalam sel tubuh (glikogen). Glikogen digunakan untuk proses metabolisme pada bakteri Lacto bacillus doderlein. Sisa dari proses metabolisme ini akan menghasilkan asam laktat yang menjaga keasaman vagina yaitu 3,8-4,2. Pada saat ovulasi terjadi proses sekresi pada endometrium yang dipengaruhi oleh hormon progesteron. Hormon progesteron menyebabkan pengeluaran sekret yang lebih kental seperti jeli. (Qiao, Cui and Cui, 2007). Kemaluan wanita merupakan tempat yang paling sensitif dan merupakan tempat yang terbuka sehingga kuman sangat mudah masuk. Secara anatomi alat kelamin wanita berdekatan dengan anus dan uretra sehingga kuman yang berasal dari anus dan uretra tersebut sangat mudah masuk. Kuman yang masuk ke alat kelamin wanita akan menyebabkan infeksi sehingga dapat menyebabkan keputihan patologis yang ditandai dengan gatal, berbau, dan berwarna kuning kehijauan. (Qiao, Cui and Cui, 2007). Jenis Keputihan. Keputihan dapat dibedakan menjadi dua jenis keputihan yaitu: keputihan normal (fisiologis) dan keputihan abnormal (patologis).Keputihan Normal. Keputihan normal dapat terjadi pada masa menjelang menstruasi, pada sekitar fase sekresi antara hari ke 10-16 menstruasi. Keputihan yang fisiologis terjadi akibat pengaruh hormon estrogen dan progesteron yang dihasilkan selama proses ovulasi. Setelah ovulasi, terjadi peningkatan vaskularisasi dari endometrium yang menyebabkan endometrium menjadi sembab. Kelenjar endometrium menjadi berkelok-kelok dipengaruhi oleh hormon estrogen dan progesteron dari korpus luteum sehingga mensekresikan cairan jernih yang dikenal dengan keputihan. (Qiao, Cui and Cui, 2007). Ciri-ciri dari keputihan fisiologis adalah cairan berwarna bening, kadang-kadang putih kental, tidak berbau, dan tanpa disertai dengan keluhan, seperti rasa gatal, nyeri, dan terbakar serta jumlahnya sedikit. Faktorfaktor yang dapat menyebabkan keputihan fisiologis adalah : Bayi yang baru lahir kira- kira 10 hari, keputihan ini disebabkan oleh pengaruh hormon estrogen dari ibunya; Masa sekitar menarche atau pertama kalinya haid datang, keadaan ini ditunjang oleh hormon estrogen; Masa di sekitar ovulasi karena poduksi kelenjarkelenjar rahim dan pengaruh dari hormon estrogen serta progesterone; Seorang wanita yang terangsang secara seksual. Kehamilan yang mengakibatkan meningkatnya suplai darah ke vagina dan mulut rahim, serta penebalan dan melunaknya selaput lendir vagina;Akseptor kontrasepsi pil yang mengandung hormon estrogen dan progesteron yang dapat meningkatkan lendir servik menjadi lebih encer; Pengeluaran lendir yang bertambah pada 
wanita yang sedang menderita penyakit kronik (Qiao, Cui and Cui, 2007). Keputihan Abnormal Keputihan abnormal dapat terjadi pada semua infeksi alat kelamin (infeksi bibir kemaluan, liang senggama, mulut rahim, jaringan penyangga, dan pada infeksi karena penyakit menular seksual). Ciriciri keputihan patologik adalah terdapat banyak leukosit, jumlahnya banyak, timbul terus menerus, warnanya berubah (biasanya kuning, hijau, abu-abu, dan menyerupai susu), disertai dengan keluhan (gatal, panas, dan nyeri) serta berbau (apek, amis, dan busuk). Faktorfaktor yang memicu keputihan abnormal adalah :Kelelahan Fisik, Ketegangan Psikis, Kebersihan Diri (Qiao, Cui and Cui, 2007). Kesehatan reproduksi mungkin merupakan konsep dan kesadaran baru. Namun bukan kebetulan jika Alquran banyak menyinggung masalah kesehatan reproduksi sejak 1400 tahun lalu. Alquran menyebut kata farji atau furuj (alat kemaluan) tak kurang dari tujuh kali. Bahkan dalam QS. Al-Mu'minun/23:5 disebutkan bahwa menjaga farji dengan baik adalah salah satu tanda mu'min yang sukses di mata Allah. (Rofiah, Nur. 2020)

Artinya : "Dan orang-orang yang selalu menjaga faraj (kemaluan) mereka." (QS. Al-Mu'minun : 5)

Dampak Keputihan. Keputihan fisiologis dan patologis mempunyai dampak pada wanita. Keputihan fisiologis menyebabkan rasa tidak nyaman pada wanita sehingga dapat mempengaruhi rasa percaya dirinya. Keputihan patologis yang berlangung terus menerus akan menganggu fungsi organ reproduksi wanita khususnya pada bagian saluran indung telur yang dapat menyebabkan infertilitas. Pada ibu hamil dapat menyebabkan keguguran, Kematian Janin dalam Kandungan (KJDK), kelainan kongenital, lahir premature. (Qiao, Cui and Cui, 2007).

Cara Mencegah Keputihan. Cara pencegahan keputihan yang sering terjadi pada remaja baik secara fisiologis ataupun patologis, antar lain : Menjaga kebersihan alat kelamin, Menjaga kebersihan pakaian dalam, Tidak bertukar handuk, Menghindari celana ketat, Menghindari cuci vagina, Mencuci tangan sebelum mencuci alat kelamin, Sering mengganti pembalut, Mengelola strees (Qiao, Cui and Cui, 2007). Siklus menstruasi adalah tanda proses kematangan organ reproduksi yang dipengaruhi oleh hormon tubuh. Peranan siklus menstruasi berhubungan dengan tingkat kesuburan perempuan itu sendiri. Siklus menstruasi adalah tanda proses kematangan organ reproduksi yang dipengaruhi oleh hormon tubuh. Peranan siklus menstruasi berhubungan dengan tingkat kesuburan perempuan (Islamy and Farida, 2019). Siklus ini secara teratur berlangsung jika seorang remaja telah menginjak usia 17-18 tahun. Namun, ada juga beberapa orang yang mengalami menstruasinya terjadi setelah 3-5 tahun dari usia menarche. Pola menstruasi normal berlangsung setiap 21-35 hari sekali, adapun lama hari menstruasi dapat berlangsung selama 3-7 hari. (Islamy and Farida, 2019). Salah satu hal penting dalam konsep pendidikan kesehatan reproduksi adalah membangun karakter yang mendukung terjaganya kesehatan reproduksi, yaitu tanggungjawab dan menghormati alat reproduksi sendiri, maupun orang lain. Hal ini sejalan dengan ayat-ayat Alquran tentang akhlak dalam memperlakukan alat reproduksi. Misalnya akhlak memperlakukan perempuan ketika menjalani menstruasi, yaitu pada surah Al-Baqarah : 222. (Rofiah, Nur. 2020)

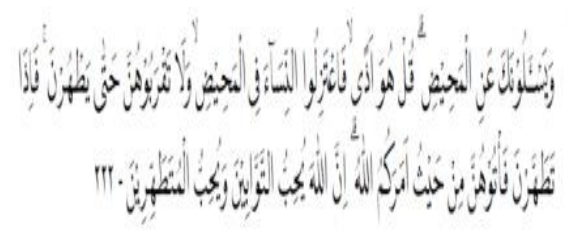

Artinya :

Mereka bertanya kepadamu tentang menstruasi. Katakanlah bahwa 
menstruasi adalah sesuatu yang bisa menimbulkan rasa sakit. Maka jauhilah istri-istri ketika menstruasi dan janganlah dekati mereka (berhubungan seksual) sampai mereka suci. Dan jika mereka telah suci, maka datangilah mereka (berhubungan seksual) dengan cara yang diperintahkan Allah. Sesungguhnya Allah mencintai orangorang yang bertaubat dan orang-orang yang menyucikan diri. (QS. Al-Baqarah :222)

Gangguan siklus menstruasi terdiri dari 2 macam, yaitu polimenorea dan oligomenorea. Polimenorea adalah siklus menstruasi dengan jumlah rentang hari kurang dari 21 hari dan atau volume darah sama atau lebih banyak dari volume darahan menstruasi biasanya. Gangguan ini mengindikasikan gangguan pada proses ovulasi, yaitu fase luteal yang pendek. Polimenorea menyebabkan unovulasi pada wanita karena sel telur tidak dapat matang sehingga pembuahan sulit terjadi. (Islamy and Farida, 2019). Oligomenorea adalah siklus menstruasi dengan durasi lebih dari 35 hari. Volume perdarahan umumnya lebih sedikit dari volume perdarahan menstruasi biasanya. Gangguan jenis ini berakibat ketidaksuburan dalam jangka panjang karena sel telur jarang diproduksi sehingga tidak terjadi pembuahan. Oligomenorea tidak berbahaya pada wanita, namun dapat berpotensi sulit hamil karena tidak terjadi ovulasi. (Islamy and Farida, 2019). Gangguan hormonal, status gizi, tinggi rendahnya IMT (Indeks Massa Tubuh), dan tingkat stress adalah faktorfaktor yang mengakibatkan timbulnya gangguan siklus menstruasi. Terdapat hubungan antara IMT dengan siklus menstruasi. Penurunan IMT berakibat pada peningkatan durasi siklus menstruasi. Seseorang dengan status gizi overweight berisiko mengalami anovulatory chronic. Wanita dengan kondisi ini, cenderung memiliki sel - sel lemak yang lebih banyak sehingga produksi hormone estrogen juga menjadi berlebih. (Islamy and Farida, 2019). Adapun wanita dengan status gizi underweight, cenderung kekurangan sel lemak sehingga produksi hormon estrogen berkurang. Hal ini berdampak pada kejadian ketidakteraturan siklus menstruasi. Tingkat stress berhubungan dengan siklus menstruasi karena stres berhubungan dengan tingkat emosi, alur berpikir, dan kondisi batin seseorang. Faktor stres dapat mempengaruhi produksi hormone kortisol yang berpengaruh pada produksi hormon estrogen wanita. Hasil penelitian menyebutkan bahwa sekitar 22,1\% wanita dengan gangguan psikologis, mengalami siklus menstruasi tidak teratur. (Islamy and Farida, 2019)

Cara Menjaga Kesehatan Daerah V. Cara pencegahan keputihan yang sering terjadi pada remaja baik secara fisiologis ataupun patologis, antar lain :Menjaga kebersihan alat kelamin. Menjaga kebersihan pakaian dalam, Tidak bertukar handuk, Menghindari celana ketat, Menghindari cuci vagina, Mencuci tangan sebelum mencuci alat kelamin, Sering mengganti pembalut (Kocjan, 1998)

Tata Cara Bersuci . Tata cara mandi junub tersebut sesuai hadis Nabi SAW:

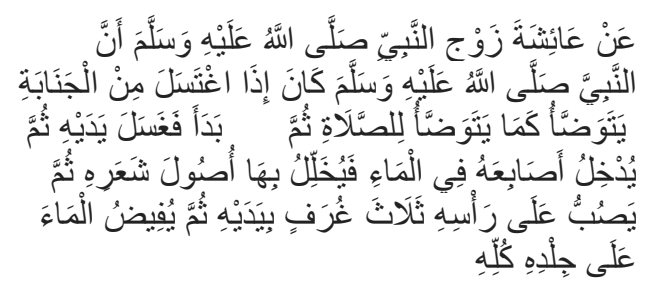

Dari Aisyah istri Nabi shallallahu alaihi wasallam, bahwa jika Nabi shallallahu alaihi wasallam mandi karena janabat, beliau memulainya dengan mencuci kedua telapak tangannya, kemudian berwudlu sebagaimana wudlu untuk shalat, kemudian memasukkan jari-jarinya ke dalam air lalu menggosokkannya ke kulit kepalanya, kemudian menyiramkan air ke atas kepalanya dengan cidukan kedua telapak tangannya sebanyak tiga kali, kemudian beliau mengalirkan air ke 
seluruh kulitnya." (HR. Bukhari) [No. 248 Fathul Bari] Shahih.

\section{SIMPULAN}

Peningkatan pengetahuan sebesar $100 \%$ dan perilaku $90 \%$ dalam kesehatan reproduksi berbasis thibun nabawi kegiatan berkelanjutan yang berupa pendampingan kepada remaja tentang kesehatan reproduksi.

\section{PERSANTUNAN}

Program pengabdian masayarakat ini bisa terlaksana berkat dukungan dari Hibah Pengabdian Kepada Masyarakat Ristek-Brin tahun 2021. Riyani Wulandari, M.Kep (Rektor Universitas Aisyiyah Surakarta .Bapak Yoseph selaku Lurah Pucangsawit dan masyarakat kampung KB Pucangsawit Surakarta yang berkontribusi besar terhadap pelaksanaan pengabdian ini.

\section{DAFTAR PUSTAKA}

Ernawati, H. (2018) 'Pengetahuan Kesehatan Reproduksi Remaja Di Daerah Pedesaan', Indonesian Journal for Health Sciences, 2(1), p. 58. doi: 10.24269/ijhs.v2i1.820.
Islamy, A. and Farida, F. (2019) 'Faktor-Faktor Yang Mempengaruhi Siklus Menstruasi Pada Remaja Putri Tingkat Iii', Jurnal Keperawatan Jiwa, $7(1), \quad$ p. $13 . \quad$ doi: 10.26714/jkj.7.1.2019.13-18.

Kocjan, R. (1998) 'Analysis of some metal ions using silica gel modified with acid orange 7 as a sorbent', Hungarian Journal of Industrial Chemistry, 26(4), pp. 263-267.

Rofiah, Nur. (2020) Tanggungjawab dalam Menggunakan Alat Reproduksi. https://swararahima.com/2020/01/14/tan ggungjawab-dalam-menggunakan-alatreproduksi/. (Diakses Pada Tanggal 29 Mei 2021)

Qiao, D., Cui, P. and Cui, H. (2007) 'Target selection and accessibility for rendezvous with a Near-Earth asteroid mission', Earth, Moon and Planets, 100(3-4), pp. 137-156. doi: 10.1007/s11038-006-9134-2. 